\title{
Soil degradation challenges for sustainable agriculture in tropical India
}

\author{
Ch. Srinivasarao ${ }^{1, *}$, S. Rakesh ${ }^{1}$, G. Ranjith Kumar ${ }^{1}$, R. Manasa ${ }^{1}$, \\ G. Somashekar ${ }^{1}$, C. Subha Lakshmi ${ }^{1}$ and Sumanta Kundu ${ }^{2}$ \\ ${ }^{1}$ Indian Council of Agricultural Research (ICAR)-National Academy of Agricultural Research Management, Rajendranagar, \\ Hyderabad 500 030, India \\ ${ }^{2}$ ICAR-Central Research Institute for Dryland Agriculture, Hyderabad 500 059, India
}

Soil degradation is a pervasive, systemic phenomenon and an urgent priority in order to ensure human wellbeing, protect biodiversity and ecosystem services. Agriculture sector is frequently affected by soil loss resulting into unproductive soil and lowered crop yields. This article focuses on critical sustainable challenges of Indian agriculture, soil degradation status and mitigation strategies as well as policies and management response options in respect of development of degraded lands. It also provides policymakers with the necessary information to develop appropriate mitigation technologies at the local, regional and national scale.

Keywords: Soil degradation, sustainable agriculture, mitigation strategies, policies.

FROM the very beginning, agriculture sector is playing a prime role in the Indian economy. According to the International Monetary Fund's (IMF's) World Economic Outlook, the country's gross domestic product (GDP) projected as US\$ 2972 billion as per 2019 prices. In exchange rate basis, India subsidizes $3.36 \%$ of the world's total GDP. Foreign trade is completely linked with agriculture sector as it accounts for about $14.7 \%$ of the total earnings from the export of goods. In India, the agriculture sector occupies roughly $46 \%$ of land area and $43 \%$ of total geographical area (TGA) according to the land-use statistics report. The 2011 census indicates that, $69 \%$ of the Indian population is still living in rural areas. By 2027 , the Indian population is estimated to be 1.47 billion which will be higher than that of China and by 2059, it is projected to reach 1.65 billion which is way too large compared to our present resources. To meet the requirements of this burgeoning population, we need to produce more food. During 2017-18, the production of coarse cereals, pulses, oil seeds, milk, eggs, meat and fish was about $46.99,25.23,31.31,176.30,95.25,7.71$ and 12.61 million tonnes $(\mathrm{mt})$ respectively. Due to population pressure, by 2050 the total foodgrain production should be increased to $377 \mathrm{mt}$; it was $284 \mathrm{mt}$ during 2017-18

*For correspondence. (e-mail: chsrao_director@naarm.org.in) according to the Indian Council of Agricultural Research (ICAR) Data Book, 2019. There is a 30\% loss of the total food produced annually in India, mainly during the production, transport and storage stages of the supply chain. Escalating population in the country poses several problems related to soil degradation. Also, soil degradation under intensive agriculture is being widely documented in India as lowered crop yields and productivity compared to other countries, high external input usage and declining profits, soil-use intensity and changing cropping patterns ${ }^{1,2}$.

\section{Sustainability challenges of Indian agriculture}

Sustainable development that preserves soil, water, plant and animal genetic resources, is environmentally safe, economically feasible and socially acceptable, and also ensures the achievement and satisfaction of human needs for the existing and coming generations. So to attain long-term development in agriculture, the optimal usage of human resources, as well as natural, economic and technological resources is necessary ${ }^{3}$. The lithospheric part of the earth, which is comprised of solid rock material is known as land. On the other hand, soil is the surface covering of land (almost top $30 \mathrm{~cm}$ ) and acts as a medium for plant growth. Land degradation is one of the prominent problems of mankind which not only reduces the production capacity of an area, but also affects the overall ecosystem ${ }^{4}$. Various types of physical, chemical and biological land degradation result in degradation of soil quality (Figure 1).

In addition, chemical fertilizers coupled with inappropriate irrigation management also result in worsening of groundwater quality in the country. The impact of chemicals on groundwater quality is much higher in shallow and unconfined aquifers. Majority of the Indian rural population uses water for domestic purpose from shallow private boreholes which are contaminated by nitrate $\left(\mathrm{NO}_{3}^{-}\right)$pollution ${ }^{5}$. Rapid human-induced secondary salinity in the last few decades has rendered vast tracts of land in dryland and irrigated regions of the world uncultivable $^{6}$. Annually, $0.25-0.5 \mathrm{~m}$ ha agricultural lands is lost due to secondary salinization ${ }^{7}$. 


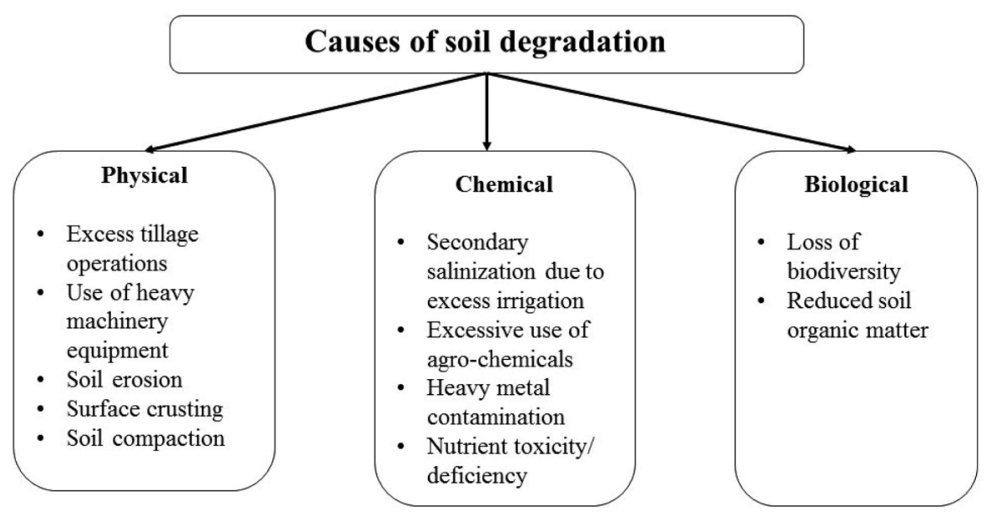

Figure 1. Different types of soil degradation.

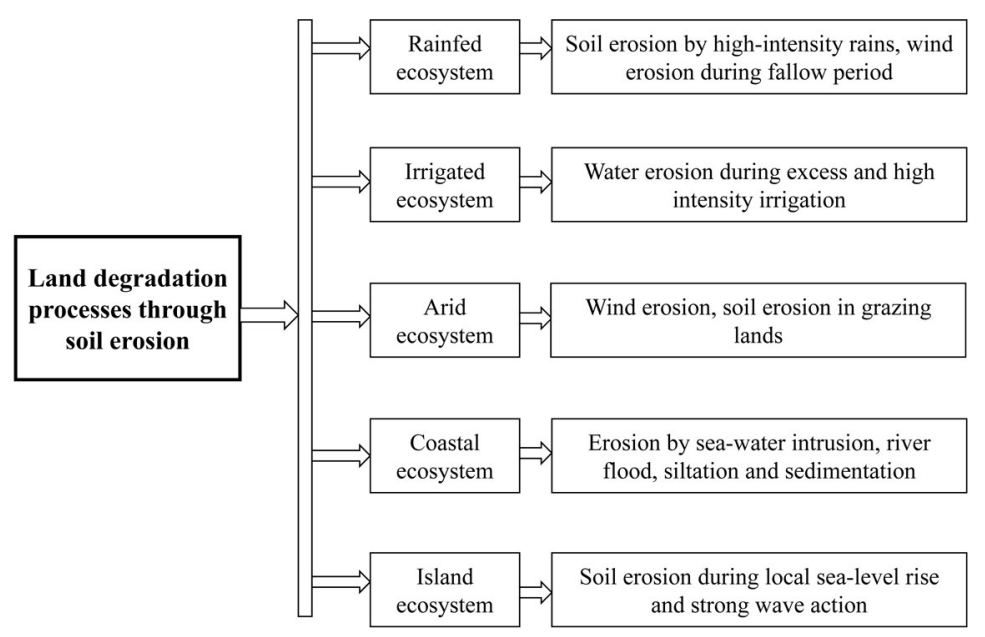

Figure 2. Soil erosion-led land degradation processes in different ecosystems of India.

Expected land scarcity and a drastic reduction in crop yields and productivity of food crops under the scenario of climate change are foreseen by 2050. Changing temperature and rainfall patterns and intensity due to increased extreme events of climate change, soil degradation as well as pest and disease infestation impose serious threats on traditional agricultural systems ${ }^{8}$. The main causes of low productivity are excessive pressure of population on land, social environment, land degradation, uneconomic land holdings, uncertain monsoons and inadequate irrigation facilities, incidence of pests and diseases, etc. ${ }^{9}$.

\section{Status of soil degradation}

Soil is the most affected natural resource through land degradation; thus it receives more attention than other natural resources. Soil erosion (water and wind erosion processes) and removal of vegetative cover (human activities) are the key reasons for the degradation of soil (Figure 2). Approximately more than 5000 tonnes of topsoil is being eroded every year, and nearly $30 \%$ of soil (about 1600 tonnes) is lost to the sea in the form of river flow $^{10}$. On an average, every year India loses approximately $0.8,1.8$, and $26.3 \mathrm{mt}$ of $\mathrm{N}, \mathrm{P}$ and $\mathrm{K}$ respectively $^{11}$. The 2010 published data of Indian Council of Agricultural Research (ICAR) and National Academy of Agricultural Sciences (NAAS) about soil degradation provided by different institutions show that $120.72 \mathrm{~m}$ ha of the land is degraded every year out of $328.73 \mathrm{~m}$ ha. Figure 3 shows the percentage of degraded land to total ground area in different states of India ${ }^{2}$. According to the desertification and land degradation atlas of India 2016 by the Indian Space Research Organisation, most of the land degradation is contributed by the following states in ascending order: Telangana, Madhya Pradesh, Odisha, Jharkhand, Karnataka, Jammu \& Kashmir, Gujarat, Maharashtra and Rajasthan. The remaining states individually contribute $<1 \%$. The most significant process of land degradation in dry, sub-humid and semi-arid regions is water erosion and removal of vegetation, whereas in arid regions wind erosion dominates.

Water and wind erosion are the major land degradation causes which contributes more than $70 \%$ and salinity contribute $15 \%$ of the total degraded area ${ }^{12}$. According 


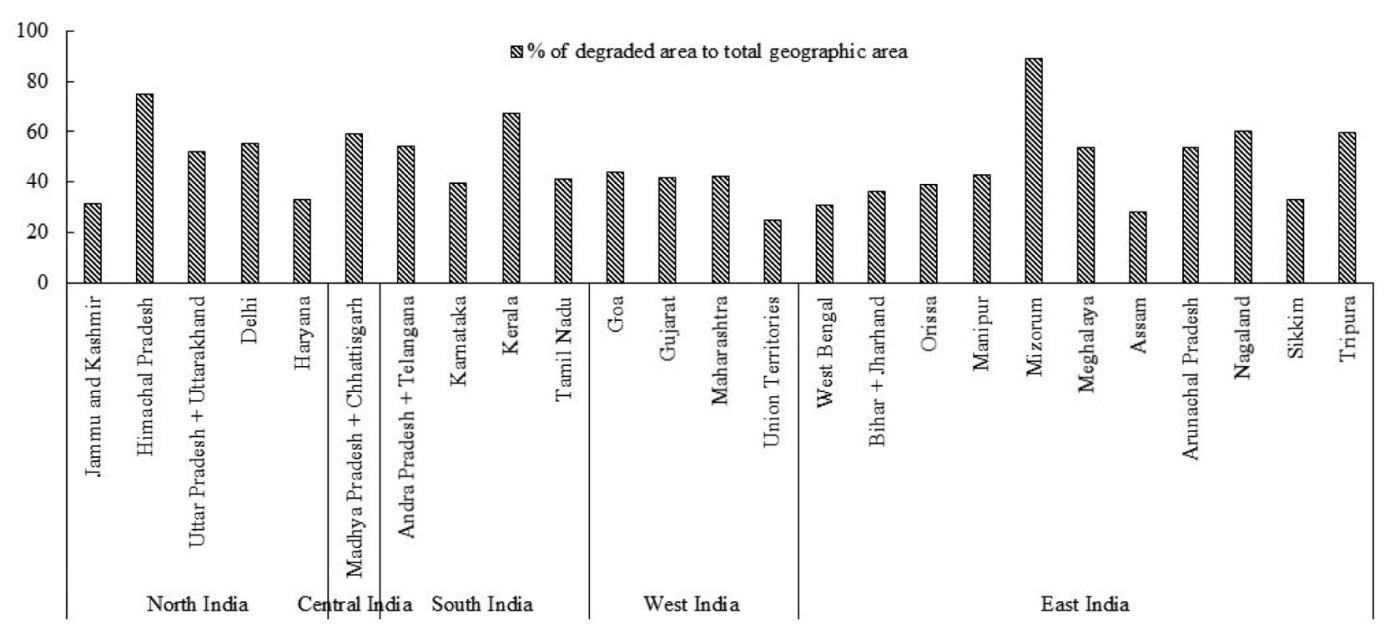

Figure 3. Status of degraded land areas in different states of India ${ }^{2}$.

to region-wise statistics, central, northeastern and southern regions are badly affected. Nearly $50 \%$ of the total area of these regions is affected by land degradation; however, the statistics differs based on the method of estimation and source. The National Remote Sensing Agency (NRSA) estimations based on remotely sensed satellite data are expected to be more authentic than other estimations.

The population of our country has increased from 36.1 crores in 1951 to 125.03 crores in 2011. Thus the area under agriculture also increased from $119 \mathrm{~m}$ ha in 1950 51 to $140 \mathrm{~m}$ ha in 2014-15. On the other hand, area under uncultivable barren land, cultivable wasteland and fallow land has shown significant decrease from 1950 onwards due to urbanization and developmental activities. We are constantly stressing the land resources as we cannot increase the land area for higher productivity.

\section{Technologies and mitigation strategies}

There are several panaceas for the issues and processes of soil degradation. Table 1 provides an overview of the response level of different technologies with respect to financial, technological, political and other capacities for appropriate selection of land restoration techniques.

\section{Contour bunding, terracing and other engineering structures}

Contour bunding is an earthen embankment across land slopes that divides the area into strips and restricts water flow by reducing the amount and velocity of the run-off. Such bunds protect soils from a variety of erosions to the extent of 25-162 tonnes/ha/year and are suitable for slope of about $6 \%$. Graded bunds are suitable in areas where rainfall is $>80 \mathrm{~cm} /$ year, irrespective of soil texture. It consists of a wide-low embankment constructed on the lower edge of a channel. These bunds are used at about $2-10 \%$ land slope. Bench terracing is one of the most popular soil conservation practices adopted on sloping and undulating lands having slope between $16 \%$ and $33 \%$. Original slope is converted into level fields; all the manure and fertilizers applied are retained in the field, thus helping in proper water management. Contour trenches are suitable for high-rainfall hilly areas having a slope of steeper than $33 \%$ with badly eroded soil. Length is $3-3.65 \mathrm{~m}$ and the inter-space between trenches is 2.4 and $3 \mathrm{~m}$. Due to construction of contour bunds in maize crop cultivation, around $21 \%$ of the crop land was saved, with $10 \%$ increase in yield ${ }^{13}$.

\section{Intercropping, crop rotation and contour farming}

Intercropping system involves the cultivation of two or more crops simultaneously in the same piece of land with distinct row arrangement for efficient utilization of available natural resources that enhance the overall crop productivity. It is suitable for landholding farmers who have limited land resources and low productive soils. In an intercropping system, maize-cowpea/ladies finger, maize is sown at a wider row spacing $(60-90 \mathrm{~cm})$ that provides enough space for soil erosion, and cultivating cowpea ${ }^{14}$ and ladies finger ${ }^{15}$ in between the maize crop protects the soil from erosion. Introduction of legumes in maize ${ }^{16}$ aids in the provision of atmospheric nitrogen $\left(\mathrm{N}_{2}\right)$, mitigation of the drought effects by acting as a live mulch and reduction of soil erosion and evaporation ${ }^{17}$. Especially, in sandy loam textured soils, soil erosion may be reduced by a good canopy cover during early stages. In the maize-wheat cropping system, inclusion of cowpea (Table 2) resulted in highest gross return (11\%), net return $(17 \%)$ and $\mathrm{B}: \mathrm{C}$ ratio $(7 \%)$ in maize + cowpea $(1: 1)$-wheat treatment than pure maize $(90 \times 20 \mathrm{~cm})-$ wheat plots ${ }^{18}$. 
Table 1. Response level of different technologies for soil degradation

\begin{tabular}{|c|c|c|c|c|c|c|}
\hline \multirow[b]{2}{*}{ Technology } & \multicolumn{6}{|c|}{ Response level } \\
\hline & $\begin{array}{c}\text { Environmental } \\
\text { desirability }\end{array}$ & $\begin{array}{l}\text { Technical } \\
\text { feasibility }\end{array}$ & $\begin{array}{c}\text { Political } \\
\text { acceptability }\end{array}$ & $\begin{array}{c}\text { Cultural } \\
\text { acceptability }\end{array}$ & $\begin{array}{c}\text { Social } \\
\text { acceptability }\end{array}$ & $\begin{array}{l}\text { Economic } \\
\text { feasibility }\end{array}$ \\
\hline Contour bunding, terracing and other engineering structures & $\mathrm{H}$ & $\mathrm{M}-\mathrm{H}$ & M & $\mathrm{M}-\mathrm{H}$ & $\mathrm{M}-\mathrm{H}$ & M \\
\hline Intercropping & $\mathrm{M}-\mathrm{H}$ & $\mathrm{L}-\mathrm{M}$ & $\mathrm{L}$ & M & M & $\mathrm{H}$ \\
\hline Crop rotation & $\mathrm{H}$ & $\mathrm{M}-\mathrm{H}$ & $\mathrm{L}$ & M & M & $\mathrm{H}$ \\
\hline Contour farming & $\mathrm{H}$ & $\mathrm{M}-\mathrm{H}$ & M & $\mathrm{M}-\mathrm{H}$ & $\mathrm{M}-\mathrm{H}$ & M \\
\hline Integrated nutrient management & $\mathrm{H}$ & $\mathrm{M}-\mathrm{H}$ & M & $\mathrm{M}-\mathrm{H}$ & $\mathrm{M}-\mathrm{H}$ & $\mathrm{H}$ \\
\hline Sub-soiling & $\mathrm{M}-\mathrm{H}$ & M & $\mathrm{L}$ & $\mathrm{M}-\mathrm{H}$ & M & M \\
\hline Conservation agriculture & $\mathrm{H}$ & $\mathrm{M}-\mathrm{H}$ & $\mathrm{L}$ & $\mathrm{H}$ & $\mathrm{H}$ & $\mathrm{H}$ \\
\hline Integrated farming systems & $\mathrm{H}$ & $\mathrm{M}-\mathrm{H}$ & M & $\mathrm{H}$ & $\mathrm{M}-\mathrm{H}$ & M \\
\hline Agroforestry & $\mathrm{H}$ & $\mathrm{M}-\mathrm{H}$ & M & $\mathrm{H}$ & $\mathrm{M}-\mathrm{H}$ & M \\
\hline Reclamation of acid and salt-affected soils & $\mathrm{H}$ & $\mathrm{M}-\mathrm{H}$ & M & $\mathrm{H}$ & $\mathrm{H}$ & M \\
\hline
\end{tabular}

Note: H, High; M-H, Moderate to high; M, Moderate; V, Variable; L-M, Low to moderate; L, Low.

Table 2. Economics (mean of five years) of maize-wheat cropping system with different treatments ${ }^{18}$

\begin{tabular}{|c|c|c|c|}
\hline Treatment & Gross return $\left(\mathrm{US} \$ \mathrm{ha}^{-1}\right)^{* *}$ & Net return (US\$ ha ${ }^{-1}$ ) & $\mathrm{B}: \mathrm{C}$ ratio \\
\hline Pure maize $(90 \times 20 \mathrm{~cm})-$ wheat & 1134 & 557 & 1.96 \\
\hline Pure maize $(150 \times 20 \mathrm{~cm})-$ wheat & 984 & 484 & 1.97 \\
\hline Maize + cowpea $(1: 2)-$ wheat & 1190 & 540 & 1.83 \\
\hline Maize + okra $(1: 2)-$ wheat & 1037 & 510 & 1.97 \\
\hline Maize + cowpea $(1: 1)-$ wheat & 1279 & 674 & 2.11 \\
\hline Maize + okra $(1: 1)-$ wheat & 1138 & 560 & 1.97 \\
\hline
\end{tabular}

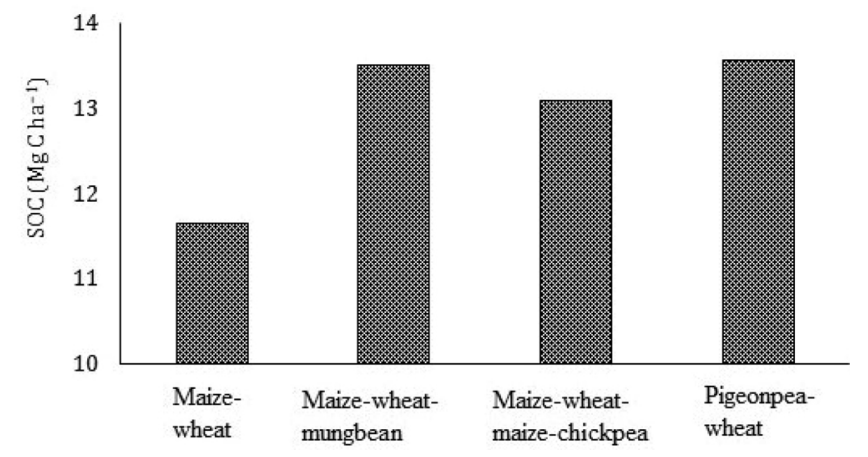

Figure 4. Soil organic carbon (SOC) as influenced by long-term crop rotation $^{20}$.

Pulse crops like pigeon pea, mung bean, cowpea, chickpea, soybean, etc. have higher root biomass, biological nitrogen-fixation capacity, and can enrich the soil with organic carbon, enhance soil fertility by redistributing the soil profile nutrients ${ }^{19}$. After long-term continuous cropping, the pulse inclusive crop rotations (Figure 4) brought significant changes in soil organic carbon (SOC) compared to the cereal-cereal cropping system ${ }^{20}$.

Contour farming is an effective practice of tillage, planting and other farming operations carried on the contour of the field slope in order to control soil erosion and increase crop productivity; it is suitable for moderate slopes. Contour ridging results in rainwater ponding, reduces velocity of run-off and soil erosion, and increases infiltration $^{21}$. Soil nutrients in the run-off are retained better in contour ridge tillages. Cultivation and planting along contour lines reduced soil and water loss to the tune of $49.5 \%$ and $32 \%$ respectively.

\section{Integrated nutrient management and organic amendments}

Practice of integrated nutrient management (INM) by combining organic amendments with appropriate management options is considered as a viable strategy to combat climate change and improve carbon stocks ${ }^{22,23}$. Combined application of 50\% NPK and farmyard manure (FYM)@ 10 tonne ha ${ }^{-1}$ in groundnut crop increased yield and exerted a significant effect on the mineralization of $\mathrm{SOC}^{24}$. Cereal crop residues retained on the field also aid in the provision of plant nutrient sources ${ }^{25}$.

Application of azolla compost along with recommended doses of NPK helped effectively build-up soil carbon $(27.43 \%)$ followed by NPK + cowdung (22.76\%) over NPK alone ${ }^{26}$. Azolla application also improved the soil carbon storage $\left(2.88 \mathrm{mg} \mathrm{ha}^{-1}\right)$ capacity with grain yield of $6.55 \mathrm{mg} \mathrm{ha}^{-1}$ compared to other treatments (Table 3). Generally, in the slope areas $(0.5-2.0 \%)$ run-off and soil loss are higher. In such areas, INM practice efficiently protect the soil from losses. Application of recommended rate of fertilizer along with FYM (Figure $5 a$ and $b$ ), minimizes soil run-off and losses ${ }^{27}$.

Adoption of INM in the drylands under groundnutbased cropping system registered higher $\mathrm{C}$ accumulation rates $\left(0.45\right.$-tonne $\mathrm{ha}^{-1}$ year $\left.^{-1}\right)$ compared to the other 
Table 3. Comparison of grain yield and C fixed under integrated nutrient management (INM) in monsoon rice ecosystem ${ }^{26}$

\begin{tabular}{lccc}
\hline Treatment & Total C fixed in grain $\left(\mathrm{mg} \mathrm{ha}^{-1}\right)$ & Grain yield $\left(\mathrm{mg} \mathrm{ha}^{-1}\right)$ & \% increase in yield over control \\
\hline NPK & $2.02 \pm 0.06$ & $5.14 \pm 0.17$ & - \\
NPK + cow dung & $2.66 \pm 0.05$ & $6.31 \pm 0.11$ & 22.76 \\
NPK + green manure & $2.41 \pm 0.08$ & $5.69 \pm 0.18$ & 10.70 \\
NPK + Azolla compost & $2.88 \pm 0.07$ & $6.55 \pm 0.11$ & 27.43 \\
NPK + rice husk dust & $2.42 \pm 0.08$ & $6.01 \pm 0.16$ & 16.93 \\
$P$ value (Treatment) & 0.000 & 0.000 & 0.987 \\
Year $\times$ Treatment & 0.901 & 0.229 & \\
LSD (Treatment) & 0.109 & & \\
\hline
\end{tabular}

Table 4. Carbon accumulation rate in soil $(0-20 \mathrm{~cm})$ under different INM practices ${ }^{28}$

\begin{tabular}{|c|c|c|c|c|}
\hline \multirow[b]{2}{*}{ Crop production system } & \multirow[b]{2}{*}{ Soil order } & \multirow[b]{2}{*}{ Suggested INM practice } & \multicolumn{2}{|c|}{$\mathrm{C}$ accumulation (tonne $\mathrm{ha}^{-1}$ year $^{-1}$ ) } \\
\hline & & & Farmer's practice & Suggested practice \\
\hline Sorghum-based & Vertisols & $25 \mathrm{~kg} \mathrm{~N} \mathrm{ha}^{-1}$ (through FYM), $25 \mathrm{~kg} \mathrm{~N} \mathrm{ha}^{-1}$ (through urea) & 0.101 & 0.288 \\
\hline Groundnut-based & Alfisols & $50 \% \mathrm{RDF}+4$ tonne groundnut shell ha $\mathrm{ha}^{-1}$ & 0.08 & 0.45 \\
\hline Pearl millet-based & Aridisols & $50 \% \mathrm{~N}$ (inorganic fertilizer) $+50 \% \mathrm{~N}(\mathrm{FYM})$ & -0.252 & -0.110 \\
\hline Finger millet monocropping & Alfisols & FYM 10 tonne $+100 \%$ RDF (NPK) & 0.046 & 0.378 \\
\hline Rice-based & Inceptisols & $100 \%$ organic $(\mathrm{FYM})$ & -0.014 & 0.128 \\
\hline Soybean-based & Vertisols & 6 tonne FYM ha ${ }^{-1}+20 \mathrm{~kg} \mathrm{~N}+13 \mathrm{~kg} \mathrm{P}$ & -0.219 & 0.338 \\
\hline
\end{tabular}

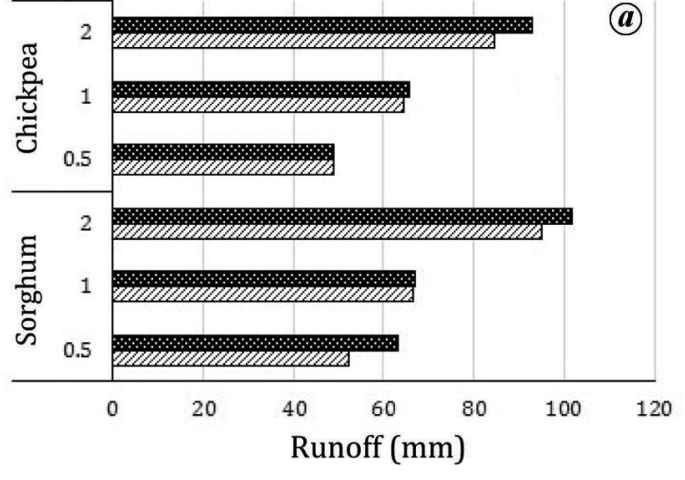

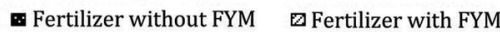

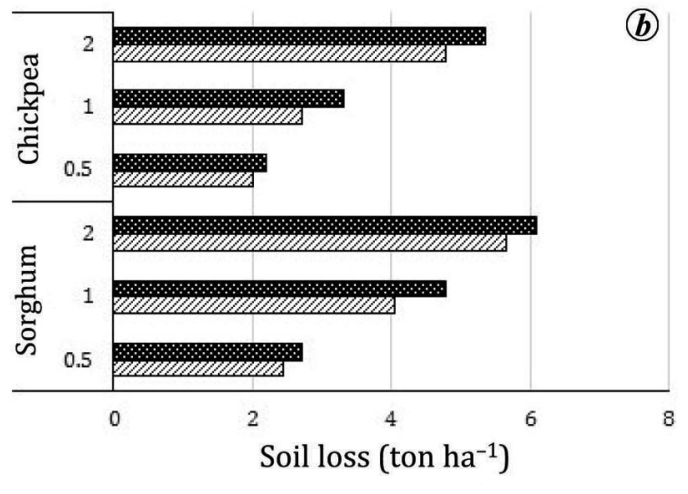

a Fertilizer without FYM घ Fertilizer with FYM

Figure 5. Runoff (a) and soil loss (b) under sorghum and chickpea at varying slopes ${ }^{27}$.

systems over farmer's practice (Table 4$)^{28}$. Each tonne of SOC increment has a yield benefit of about 0.02$0.16 \mathrm{tha}^{-1}$ among several rainfed crops ${ }^{29,30}$. The INM practice, specifically in rainfed regions of India, takes complete advantage of locally available organic resources and external fertilizers towards achieving sustainability of rainfed systems ${ }^{31}$.

\section{Subsoiling}

Soils may become deeply compacted due to heavy machinery operation during cultivation. Such compacted soils restrict the movement of water, air and roots that hampers plant growth. Soil compaction is one of the severe forms of soil degradation that affects around $11 \%$ of the land area $^{32}$. Especially, in black soils (Vertisols) such issues further increase the problems of crop cultivation. Subsoiling is an effective technique in both cropping and pastoral agriculture to alleviate soil compaction and to improve its physical condition. Subsoiling in sugarcane significantly influenced the yield and quality; it also reduced the soil bulk density and increased infiltration $\operatorname{rate}^{33}$.

\section{Conservation agriculture}

Conservation agriculture (CA) is a type of farming system that prevents degradation of arable lands through its interlinked principles, namely maintaining permanent soil cover, minimal soil disturbance and diversified cropping system ${ }^{34}$. CA minimizes soil and water loss $(45 \%$ and $50 \%$ respectively) over traditional system ${ }^{35}$. Maximum yields of maize and wheat $\left(2000\right.$ and $1700 \mathrm{~kg} \mathrm{ha}^{-1}$ respectively) were noticed under $\mathrm{CA}$ over conventional plots $\left(1570\right.$ and $950 \mathrm{~kg} \mathrm{ha}^{-1}$ respectively). Almost $58.5 \mathrm{~mm}$ of moisture was conserved in wheat under CA 

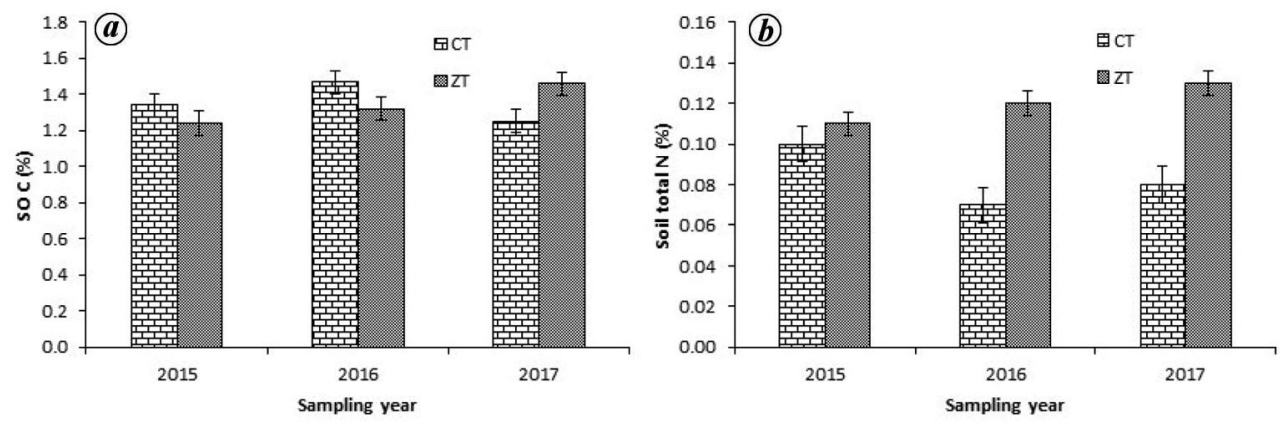

Figure 6. Effect of tillage practice (conventional tillage (CT) and zero-tillage (ZT)) on $(\boldsymbol{a})$ SOC $(n=3)$ and (b) total soil $\mathrm{N}(n=3)$ at $0-15 \mathrm{~cm}$ depth for a three-year period ${ }^{39}$.

Table 5. Crop productivity and conservation efficiency as affected by conservation agriculture under $2 \%$ slope in maize-wheat cropping ${ }^{35}$

\begin{tabular}{lcc}
\hline Particulars & $\begin{array}{c}\text { Conventional } \\
\text { agriculture }\end{array}$ & $\begin{array}{c}\text { Conservation } \\
\text { agriculture }\end{array}$ \\
\hline Maize grain yield & 1570 & 2000 \\
Wheat grain yield after maize & 950 & 1700 \\
Equivalent yield of wheat & 2320 & 3470 \\
$\quad\left(\mathrm{~kg} \mathrm{ha}^{-1}\right)$ & - & 4.0 \\
Oil yield & - & 610 \\
Dry grass yield (kg ha year $\left.^{-1}\right)$ & - & 2100 \\
Weed biomass for mulching & 39.8 & 21.9 \\
Water loss (\% of rainfall) & 7.2 & 3.5 \\
Soil loss (tonne ha year $\left.^{-1}\right)$ & 28.1 & 58.5 \\
Moisture conservation for wheat & & \\
$\quad$ compared to fallow (Mm) & & \\
\hline
\end{tabular}

compared to fallow systems under conventional agriculture (Table 5).

Zero tillage (ZT) is highly effective for the Himalayan regions of India due to its minimum cost of cultivation, moisture retention and SOC protection ${ }^{36}$. Combining ZT system or CA with various organic amendments like vermicompost, FYM, poultry manure and weed mulching potentially benefits the economic and environmental status $^{37}$. Soil physical properties like bulk density, field capacity and porosity are improved by adopting conservation tillage ${ }^{38}$. Over a period of time, zero-tillage system enhanced the SOC and soil nitrogen status over the conventional tillage after three years (Figure 6) ${ }^{39}$.

\section{Integrated farming system and agroforestry}

Adoption of an integrated farming system (IFS) is highly advantageous to the farmers due to optimal resource utilization, employment creation and waste recycling ${ }^{40}$. It also helps solve the energy crises $^{41}$. Table 6 presents various components that are suitable for the IFS models ${ }^{42-46}$.

Introduction of forestry in the agriculture system along with dairy, apiculture, goat-rearing, etc. is an effective risk management strategy to combat drought seasons and heavy flooding ${ }^{47}$. The three important environmental benefits of adaptation of agroforestry are enhancement of water quality, carbon sequestration and soil improvement ${ }^{48}$. Important soil properties like organic carbon, cation exchange capacity (CEC), available phosphorus $(\mathrm{P})$, exchangeable potassium $(\mathrm{K})$ and magnesium $(\mathrm{Mg})$ are improved in agroforestry system, where coffee, black pepper and pipli were grown compared to natural fallow $(\text { Table } 7)^{49}$.

Compared to agricultural crops, few trees are less vulnerable to salinity. Thus cultivation of such trees helps regenerate the saline soils. Planting of Prosopis juliflora in alkaline wastelands could overcome the problem of poor root proliferation because of the vertically penetrating roots into a hard $\operatorname{pan}^{50}$. Different tree species are tolerant to saline conditions at different electrical conductivity (ECe) levels. Species such as Prosopis juliflora, Salvadora oleoides, Tamarix troupii, etc. are tolerant at high salinity $\left(\mathrm{ECe}>35 \mathrm{dS} \mathrm{m}^{-1}\right)$; species such as Tamarix articulata, Acacia farnesiana, Parkinsonia acculeat, etc. are tolerant at moderate salinity (ECe 25-35 $\mathrm{dS} \mathrm{m}^{-1}$ ); species such as Casuarina glauca, obesa, equisetifolia, Acacia tortilis, Pongamia pinnata, Eucalyptus camaldulensis, etc. are tolerant at the ECe value of 15-25 $\mathrm{dS} \mathrm{m}^{-1}$ ) and the species such as Eucalyptus tereticornis, Casuarina cunninghamiana, Acacia catechu, Dalbergia sissoo, etc. are tolerant at ECe $10-15 \mathrm{dS} \mathrm{m}^{-1}$ to reclaim the saline soils.

\section{Reclamation of acid and salt-affected soils}

Soil acidity, salinity and alkalinity are considered as the major land degradation processes in agricultural lands that are adversely affecting crop yields. Acidic soils are ameliorated by lime application. Lime raises the soil $\mathrm{pH}$ to the desired level, increases the plant nutrient availability, and minimizes Fe and $\mathrm{Al}$ toxicity ${ }^{51}$. Leaching is the only effective reclamation technique for saline soils which have a deeper water table. Application of 12-15 tonne gypsum ha $\mathrm{h}^{-1}$ at $0-15 \mathrm{~cm}$ soil depth is sufficient to reclaim highly deteriorated soil $(\mathrm{pH}>10.0)$ under rice-wheat crops rotation ${ }^{52}$. Gypsum application method is successfully promoted by the All India Coordinated Research 
Table 6. Suggested components for integrated farming system (IFS) models

\begin{tabular}{|c|c|}
\hline Components of IFS & Source \\
\hline \multicolumn{2}{|l|}{ Agriculture-dairy, fish farming, duck-rearing, horticulture, forestry. } \\
\hline Mushroom cultivation - azolla farming, kitchen gardening, fodder production, nursery, sericulture. & 42 \\
\hline \multicolumn{2}{|l|}{ Seed production - goat-rearing, poultry, pigeon-rearing, vermiculture, apiary. } \\
\hline \multicolumn{2}{|l|}{ Sheep-rearing - piggery, rabbitry, value addition } \\
\hline \multicolumn{2}{|l|}{ Crop + dairy } \\
\hline \multicolumn{2}{|l|}{ Crop + horticulture + goats + dairy } \\
\hline \multicolumn{2}{|l|}{ Crop + horticulture + goats } \\
\hline Crop + vegetables + dairy & 43 \\
\hline \multicolumn{2}{|l|}{ Dairy + horticulture + vegetables } \\
\hline \multicolumn{2}{|l|}{ Dairy + vegetables } \\
\hline \multicolumn{2}{|l|}{ Dairy + companion animals + crops } \\
\hline $\begin{array}{l}\text { Agricultural crops like rice + pea, ragi, maize, pigeon pea and groundnut, horticultural crops like banana, tapioca, } \\
\text { yam, and vegetables }+ \text { poultry and vermicomposting. }\end{array}$ & 44 \\
\hline \multicolumn{2}{|l|}{$\begin{array}{l}\text { Inter cropping with groundnut }+ \text { pigeonpea }(7: 1) \text { and maize }+ \text { black gram }(2: 2) \text {; double cropping of fodder } \\
\text { millet - green chilli system. }\end{array}$} \\
\hline $\begin{array}{l}\text { Tamarind + pearl millet or sunflower and simarouba + chickpea-based agri-horti systems; Leucaena } \\
\text { leaucocephala }(\mathrm{K}-63)+\text { gobi - sarson in rabi and fodder maize in kharif. }\end{array}$ & 45 \\
\hline \multicolumn{2}{|l|}{$\begin{array}{l}\text { Relay cropping of castor in green gram, pear millet }+ \text { cluster-bean strip cropping system }(4: 4) \text { and pearl millet }+ \\
\text { green gram }(8: 4) \text {. }\end{array}$} \\
\hline $\begin{array}{l}\text { Integrated fish-cum-duck farming; integrated paddy-cum fish farming in low-lying areas (Dhubri, Assam); } \\
\text { water reed cum-fish farming (Manipur) and duck-cum-fish integrated farming (Ri-Bhoi, Meghalaya). }\end{array}$ & 46 \\
\hline
\end{tabular}

Table 7. Important soil properties as affected by different land-use systems ${ }^{49}$

\begin{tabular}{|c|c|c|c|c|c|c|c|c|}
\hline \multirow[b]{2}{*}{ Land-use } & \multirow[b]{2}{*}{ Component } & \multirow[b]{2}{*}{$\mathrm{pH}(1: 2.5)$} & \multirow[b]{2}{*}{ Organic C $(\%)$} & \multirow[b]{2}{*}{ Available P (ppm) } & \multirow[b]{2}{*}{$\operatorname{CEC}\left(\mathrm{c} \mathrm{mol}(\mathrm{p}+) \mathrm{kg}^{-1}\right)$} & \multicolumn{3}{|c|}{$\begin{array}{l}\text { Exchangeable cations } \\
\quad\left(\mathrm{cmol}^{+}\left(\mathrm{p}^{+}\right) \mathrm{kg}^{-1}\right)\end{array}$} \\
\hline & & & & & & $\mathrm{K}$ & $\mathrm{Ca}$ & $\mathrm{Mg}$ \\
\hline Agroforestry & Coffee, pipli and black pepper & 4.80 & 1.60 & 2.90 & 9.10 & 0.30 & 0.90 & 0.80 \\
\hline Natural fallow & Grasses & 5.70 & 1.47 & 1.40 & 5.20 & 0.20 & 0.90 & 0.60 \\
\hline
\end{tabular}

Project (AICRP) at the Centres in Indore, Kanpur, Gangavathi, Tiruchirappalli and Bapatla, to reclaim alkali soils in the respective states. Incorporation of dhaincha lowered the exchangeable sodium percentage (ESP) (23.54 in 2016-17 and 22.62 in 2017-18) followed by sunhemp (26.70 in 2016-17 and 25.90 in 2017-18). Green manuring also helps in the reduction of ESP, enhances crop yields and improves the soil fertility status ${ }^{53}$. Some crop varieties are resistant to salinity, e.g. rice: CSR-10, 13, 23, 27, 36, 43, 46, 56 and 60; wheat: KRL1-4, 19, WH 157, Raj. 3077, KRL-210, 213, 283; mustard: Pusa Bold, Varuna, Kranti, CS-52, 54, 56, 58 and 60; barley: CSB 1, 2, 3, DL 200 and 348, Ratna, BH 97, AZAD, and chickpea: Karnal Chana-1 are highly tolerant to saline conditions ${ }^{52}$.

\section{Programmes and policies}

In 1977-78, the Desert Development Programme (DDP) was initiated in the country to deal with the adverse effects of desertification. In 1985, the National Wastelands Development Board (NWDB) was set-up under the Ministry of Environment and Forests (MoEF), Government of India to reverse the land degradation. To combat drought situations, in 1973-74, the Drought Prone Areas
Programme (DPAP) was launched. The Integrated Wastelands Development Programme (IWDP) was established in 1989-90. The Scheme of Soil Conservation in the Catchments of River Valley Project and Flood Prone Rivers (RVP and FPR; 1961-62) was launched to incentivize states to draw up comprehensive agriculture development plans. Reclamation and Development of Alkali and Acid Soils (RADAS) was launched in 1985-86. The National Mission for Sustainable Agriculture (NMSA) was started in 2010 to address issues regarding 'sustainable agriculture' through climate change adaptation and mitigation strategies. The Green India Mission (GIM) was launched in 2015 to enhance the country's diminishing forest cover. Pradhan Mantri Krishi Sinchayee Yojana (PMKSY) was rolled out in 2015 to achieve convergence of investments in irrigation at the field level. The Soil Health Card (SHC) scheme was launched in February 2015 to estimate the actual fertilizer dosage. The Mahatma Gandhi National Rural Employment Guarantee Act (MGNREGA) was enacted during 2005 with a major focus on improving soil fertility and soil health, soil erosion control, reclamation of degraded soils and carbon sequestration. Neem Coated Urea (NCU) scheme was introduced to improve soil health. The National Project on Organic Farming (NPOF) scheme was launched in 2004 in order to promote organic farming 
practices. Climate-smart agriculture under the National Innovations on Climate Resilient Agriculture (NICRA) was developed for strengthening the resilience of farmers to the adversaries of climate change. The National Agroforestry Policy was initiated in 2014 for carbon sequestration and to control soil erosion.

\section{Conclusion}

Understanding the key reasons for soil degradation is imperative to find appropriate solutions and mitigate the problems. Judicious management of existing resources through sustainable agricultural technologies would aid in checking soil erosion and in the effective management of degradation losses. Combining and simultaneous application of location-specific and low-cost technologies, viz. CA, diversified cropping system, crop rotation, intercropping, residue management, use of soil amendments, INM approach, agroforestry, etc. would provide advantage in optimizing resource-use efficiency and maximize the overall crop productivity, especially in the tropical regions of India. Formulation and development of location-specific strategies and mechanisms for scaling-up the technologies through proper policies and programmes at local, regional and national scale would help in finding a comprehensive solution.

\section{Way forward}

Though there has been substantial improvements in checking soil degradation, the visible impacts of these on the ground is inadequate. A short-term analysis would suggest the following:

- Development of authentic estimation protocols to better understand and quantify the biodiversity loss and degradation is required.

- Sustainable agricultural practices are to be highly focused to deal with the soil degradation.

- Estimation of short-, medium- and long-range costs and benefits associated with mitigation of soil degradation is critical.

- Provision of scientific knowledge, tools and skills related to the monitoring of soil condition for land managers and planners is necessary.

- Support of public policies and programmes for the sustainable management of existing resources, knowledge transmission, infrastructure creation and employment generation is highly essential.

- Enforcement of frequent soil-quality monitoring at village level plays a significant role.

- Future research must concentrate on linking solutions to specific terrains and land forms, environmental situations, societies and economic demands.
1. Looking Back to Change Track: GREEN India 2047 Renewed (eds Datt, D. and Nischal, S.), TERI Press, New Delhi, 2010, p. 219.

2. Bhattacharyya, R. et al., Soil degradation in India: challenges and potential solutions. Sustainability, 2015, 7, 3528-3570; doi: $10.3390 /$ su7043528.

3. Singh, S. K. and Parihar, P., Challenges of sustainable agriculture development in India. J. Nat. Resour. Policy Res., 2015, 2(5), 355-359.

4. Alam, A., Soil degradation: a challenge to sustainable agriculture. Int. J. Sci. Res. Agric. Sci., 2014, 1(4), 50-55.

5. Singh, D. K. and Singh, A. K., Groundwater situation in India: problems and perspective. Int. J. Water Res. Dev., 2002, 18(4), $563-580$.

6. Munns, R., Genes and salt tolerance: bringing them together. New Phytol., 2005, 167, 645-663.

7. Wicke, B. et al., The global technical and economic potential of bioenergy from salt-affected soils. Energy. Environ. Sci., 2011, 4, 2669-2681.

8. Singh, R., Singh, H. and Raghubanshi, A. S., Challenges and opportunities for agricultural sustainability in changing climate scenarios: a perspective on Indian agriculture. J. Trop. Ecol., 2019, 60(2), 167-185.

9. Sreekanth, M., Hakeem, A. H., Ahmed, Q. J. P. and Rashid, I., Low productivity of Indian agriculture with special reference on cereals. J. Pharm. Pharmacol., 2017, 6(5), 239-243.

10. Dhruvanarayana, V. V. and Babu, R., Estimation of soil erosion in India. J. Irrig. Drain. Eng., 1983, 109(4), 419-434.

11. Mythili, G. and Goedecke, J., Economics of land degradation in India. In Economics of Land Degradation and Improvement - A Global Assessment for Sustainable Development (eds Nkonya, E. et al.), Springer Open, 2016, Chapter 15, pp. 431-469; doi:10.1007/978-3-319-19168-3_15.

12. Mythili, G. and Jann, G., Economics of land degradation in India; 2016; doi:10.1007/978-3-319-19168-3 15.

13. Subudhi, C. R. and Subudhi, R., Effect of contour bunding on yield of maize crop in north Eastern Ghat zones of Odisha. Int. J. Agric. Res., 2018, 5(9), 19-20; ISSN 2394-5907 (Print) and ISSN 2394-5915 (on-line).

14. Egarter-Vigl, L., Depellegrin, D., Pereira, P., De Groot, D. and Tappeiner, U., Mapping the ecosystem service delivery chain: capacity, flow, and demand pertaining to aesthetic experiences in mountain landscapes. Sci. Total Environ., 2017, 574, 436-442; http://dx.doi.org/10.1016/j.scitotenv.2016.08.209.

15. Fawusi, M. O. A., Influence of spatial arrangements on the growth: fruit and grain yields and yield components of intercropped maize and okra (Abelmoschus esculentus). Field Crops Res., 1985, 11, 345-352.

16. Singh, R. J., Ahlawat, I. P. S. and Sharma, N. K., Resource use efficiency of transgenic cotton and peanut intercropping system using modified fertilization technique. Int. J. Plant Prod., 2015, 9(4), 523-540.

17. Khola, O. P. S., Dube, R. K. and Sharma, N. K., Conservation and production ability of maize (Zea mays)-legume intercropping systems under varying dates of sowing. Indian J. Agron., 1999, 44(1), 40-46.

18. Sharma, P. C. and Singh, A., Overview of salinity management in agriculture with emphasis on India. In Quality Seed Production, Processing and Certification of Selected Field and Vegetable Crops in Salt Affected Areas, Training Manual, ICAR-Central Soil Salinity Research Institute, Karnal, 2016, pp. 1-7.

19. Kamanga, B. C., Kanyama-Phiri, G. Y., Waddington, S. R., Almekinders, C. J. and Giller, E., The evaluation and adoption of annual legumes by smallholder maize farmers for soil fertility maintenance and food diversity in central Malawi. Food Secur., 2014, 6, 45-59.

20. Venkatesh, M. S. et al., Long-term effect of crop rotation and nutrient management on soil-plant nutrient cycling and nutrient 


\section{REVIEW ARTICLES}

budgeting in Indo-Gangetic plains of India. Arch. Agron. Soil. Sci., 2017; doi:10.1080/03650340.2017.1320392.

21. Liu, Q. J., Zhang, H. Y., An, J. and Wu, Y. Z., Soil erosion processes on row sideslopes within contour ridging systems. Catena, 2014, 115, 11-18

22. Srinivasarao, Ch., Venkateswarlu, B., Dixit, S., Kundu, S. and Gayatri Devi, K., Livelihood impacts of soil health improvement in backward and tribal districts of Andhra Pradesh, CRIDA, Hyderabad, 2011, pp. 1-119.

23. Srinivasarao, Ch., Sharma, K. L. and Kundu, S., Potential soil carbon sequestration in different land use management systems in peninsular India. In Carbon Management in Tropical and SubTropical Terrestrial Systems (Ghosh, P. K. et al.), Springer Nature, 2020, pp. 3-21; https://doi.org/10.1007/978-981-13-96281.

24. Karad, G. U., Viradiya, M. B., Deshmukh, S. P. and Rajkumar, S. Long term effect of integrated nutrient management on yield and carbon mineralization under groundnut-wheat cropping system in medium black calcareous soil. Environ. Conserv., 2016, 22, 1465-1471.

25. Srinivasarao, Ch., Indoria, A. K. and Sharma, K. L., Effective management practices for improving soil organic matter for increasing crop productivity in rainfed agroecology of India. Curr. Sci., 2017, 112, 1497-1504.

26. Bharali, A., Baruah, K. K., Baruah, S. G. and Bhattacharyya, P., Impacts of integrated nutrient management on methane emission, global warming potential and carbon storage capacity in rice grown in a northeast India soil. Environ. Sci. Pollut. Res., 2017; https://doi.org/10.1007/s11356-017-0879-0.

27. CSWCR\&TI, Annual Report, Central Soil Water Conservation Research and Training Institute, Dehradun, 2012.

28. Srinivasarao, Ch. et al., Carbon sequestration strategies under rainfed production systems of India. CRIDA, Hyderabad, 2009, 102, 102 .

29. Srinivasarao, Ch. et al., Carbon stocks in different soils under diverse rainfed production systems in tropical India. Commun. Soil Sci. Plant Anal., 2009, 40, 2338-2356.

30. Srinivasarao, Ch., Lal, R., Kundu, S., Prasad Babu, M. B. B., Venkateswarlu, B. and Singh, K., Soil carbon sequestration in rainfed production systems in the semiarid tropics of India. Sci. Total Environ., 2014, 487, 587-603.

31. Srinivasarao, Ch., Subha Lakshmi, C., Sumanta Kundu, S., Ranjith Kumar, G., Manasa, R. and Rakesh, S., Integrated nutrient management strategies for rainfed agro-ecosystems of India. Indian J. Fert., 2020, 16(4), 344-361.

32. Ahmad, N., Hassan, F. and Qadir, G., Effect of subsurface soil compaction and improvement measures on soil properties. Int. J. Agric. Biol., 2007, 9, 509-513.

33. Singh, K., Choudhary, O. P. and Singh, H., Effects of subsoiling on sugarcane productivity and soil properties. J. Dairy Res., 2012, 2(1), 32-36.

34. FAO, what is conservation? Food and Agriculture Organization, Rome, Italy, 2010; http://www.fao.org/ag/ca.Ia.html (accessed on 28 October 2010).

35. Ghosh, B. N., Dogra, P., Sharma, N. K.., Bhattacharyya, R. and Mishra, P. K., Conservation agriculture impact for soil conservation in maize-wheat cropping system in the Indian sub-Himalayas. Int. Soil Water Conserv. Res., 2015, 3(2), 112-118; ISSN 2095 6339; https://doi.org/10.1016/j.iswcr.2015.05.001

36. Bhattacharyya, R., Tuti, M. D., Bisht, J. K., Bhatt, J. C. and Gupta, H. S., Conservation tillage and fertilization impacts on soil aggregation and carbon pools in the Indian Himalayas under an irrigated rice-wheat rotation. Soil Sci., 2012, 177, 218-228.

37. Bhattacharyya, R., Fullen, M. A., Davies, K. and Booth, C. A., Use of palm-mat geo textiles for rain splash erosion control. Geomorphology, 2010, 119, 52-61.

38. Singh, V. K. et al., Soil physical properties: yield trends and economics after five years of conservation agriculture based rice- maize system in north-western India. Soil Till. Res., 2016, 155, 133-148.

39. Sinha, A. K. et al., Trends in key soil parameters under conservation agriculture-based sustainable intensification farming practices in the Eastern Ganga Alluvial Plains. Soil Res., 2019; https://doi.org/10.1071/SR19162.

40. Sasikala, V., Tiwari, R. and Saravanam, M., A review on integrated farming system. J. Int. Acad. Res. Multidisc., 2015, 3(7), 319-328; ISSN: 2320-5083.

41. Manjunatha, S. B., Shivmurthy, D., Sunil, A. S., Nagaraj, M. V. and Basavesha, K. N., Integrated farming system - an holistic approach: a review. Research and Reviews: J. Agric. Allied Sci., 2014, 3(4), 30-38; ISSN: 2319-9857 p-ISSN: 2347-226X.

42. Lal, M., Patidar, J., Kumar, S. and Patidar, P., Different integrated farming system model for irrigated condition of India on basis of economic assessment: a case study: a review Int. J. Mol. Sci., 2018, 6(4), 166-175; ISSN: 2349-8528 E-ISSN: 2321-4902.

43. Tripathi, S. C. and Rathi, R. C., Livestock farming system module for hills. In Souvenir, National Symposium on Technological Interventions for Sustainable Agriculture, GBPUAT, Hill Campus, Ranichuri, 3-5 May 2011, pp. 103-104.

44. Mohanty, D., Patnaik, S. C., Jeevan Das, P., Parida, N. K. and Nedunchezhiyan, M., Sustainable livelihood: a success story of a tribal farmer, Orissa Review, September 2010, pp. 41-43.

45. Srinivasrao, Ch., Ravindra Chary, G., Mishra, P. K., Subba Reddy, G., Sankar, G. R. M., Venkateswarlu, B. and Sikka, A. K., Rainfed farming - a compendium of doable technologies, All India Coordinated Research Project for Dryland Agriculture, Central Research Institute for Dryland Agriculture, Hyderabad, 2014, p. 194.

46. Srinivasarao, Ch., Gopinath, K. A., Prasad, J. V. N. S., Prasannakumar and Singh, A. K., Climate resilient villages for sustainable food security in tropical India: concept, process, technologies institutions and impacts. Adv. Agron., 2016, 140(3), 101-214.

47. Thamizoli, P. R., Rengalakshmi, K., Senthilkumar and Selvaraju, T., Agronomic rehabilitation and livelihood restoration of tsunami affected lands in Nagapattinam District of Tamil Nadu, M.S. Swaminathan Research Foundation, Chennai, 2006, p. 31.

48. Nair, T., India to launch a brave new initiative to save the Critically Endangered Gharial. SPECIES-Mag. Spec. Surv. Commun., 2011, 21, 53.

49. Mrinmoy, D., Gulab, Y. and Anup, D., Agroforestry and soil quality improvement in Eastern Himalayas. In Conservation Agriculture for Advancing Food Security in Changing Climate Edition: Vol. 1 (eds Das, A. et al.), Today \& Tomorrow's Printers and Publishers, New Delhi, 2017, pp. 363-386.

50. Singh, G., The role of Prosopis in reclaiming high-pH soils and in meeting firewood and forage needs of small farmers. In Prosopis: Semi-Arid Fuelwood and Forage: Tree Building Consensus for the Disenfranchised, US National Academy of Sciences, Washington, DC, USA, 1996.

51. Sharma, P. D. and Sarkar, A. K., Managing acid soils for enchancing productivity. Technical Bulletin; NRM Division, KAB-II, New Delhi, 2005, p. 23.

52. Kaledhonkar, M., Babu, M. and Parbodh, S., Reclamation and nutrient management for salt-affected soils. Indian J. Fert., 2019, 15, 566-575.

53. Anon., Biennial Report 2016-18, All India coordinated research project on management of salt-affected soils and use of saline water in agriculture, ICAR-CSSRI, Karnal, 2018, pp. 1-282.

ACKNOWLEDGEMENT. We thank the Indian Council of Agricultural Research, New Delhi for financial support.

Received 19 May 2020; revised accepted 23 November 2020

doi: $10.18520 / \mathrm{cs} / \mathrm{v} 120 / \mathrm{i} 3 / 492-500$ 